\title{
EVALUASI TINDAK LANJUT PENGELAKAN PAJAK MODUS CROSS-BORDER TRANSACTION DI INDONESIA DENGAN KEBIJAKAN AUTOMATIC EXCHANGE OF INFORMATION FOR TAX PURPOSE
}

\author{
Ryan Mohammad ${ }^{a}$, Helmi Zus Rizal ${ }^{b}$ \\ a Direktorat Jenderal Pajak, Bali, Indonesia. Email: ryan.mohammad@pajak.go.id \\ b Direktorat Jenderal Pajak, Bali, Indonesia. Email: helmi.zus@pajak.go.id
}

\section{ABSTRACT}

The Implementation of Exchange of Information for Tax Purposes policy in the second quarter of 2017 is Indonesian Government efforts to mitigate tax avoidance behavior by using a cross-border transaction. In this paper, we research the effect of the policy to Indonesian resident behavior compliance with Difference-in-difference research design using cross-border deposit Indonesian resident data as a proxy for behavior compliance Indonesian resident who does cross border transaction. The observation started from the first quarter of 2008 until the first quarter of 2019, which results in the decrease of cross-border deposit Indonesian resident in Offshore Financial Centre about 25,9\%. Furthermore, the results continue that not every cross-border deposit Indonesian resident repatriated or declared in Indonesian, but shifting into other countries who had not to comply to exchange of information policies around 4,6\%. These results suggest that the implementation exchange of information for tax purpose policies had a significant role to increase the enforce compliance behavior of Indonesian resident.

Keywords: : cross-border transaction, exchange of information for tax purposes, Indonesia

\section{ABSTRAK}

Diberlakukannya kebijakan keterbukaan dan pertukaran informasi internasional untuk kepentingan perpajakan pada kuartal II tahun 2017 merupakan upaya Indonesia untuk memitigasi risiko penghindaran pajak dengan modus cross-border transaction. Dalam paper ini, penulis meneliti dampak kebijakan tersebut terhadap tingkat kepatuhan resident Indonesia dengan desain penelitian estimasi difference-in-differences menggunakan data cross-border deposit sebagai proksi atas tingkat kepatuhan resident Indonesia yang melakukan cross-border transaction sebagaimana dilakukan penelitian terdahulu. Berdasarkan pengamatan pada kuartal I 2008 sampai dengan kuartal I 2019, hasil penelitian menunjukkan terdapat penurunan cross-border deposit resident Indonesia yang ditempatkan di Offshore Financial Centre sebesar 49,64\%. Lebih lanjut, hasil penelitian menunjukkan bahwa cross-border deposit resident Indonesia yang keluar dari Offshore Financial Centre tidak sepenuhnya direpatriasi atau dideklarasi tetapi ada 
yang beralih ke negara yang tidak mematuhi kebijakan pertukaran informasi sebesar 23,86\%. Hal ini menunjukkan bahwa penerapan kebijakan keterbukaan dan pertukaran informasi internasional berpengaruh signifikan dalam meningkatkan kepatuhan yang dipaksakan terhadap resident Indonesia.

Kata kunci : kepatuhan resident Indonesia, penghindaran pajak

\section{PENDAHULUAN \\ 1.1 Latar Belakang}

Seiring dengan berkembangnya teknologi informasi dan globalisasi, aliran modal semakin mudah berpindah antar negara. Kemudahan ini berpotensi mendorong investor melakukan pengelakan pajak dengan cara menempatkan atau seolah-olah menempatkan modal di offshore atau negara Tax Haven yang memiliki tarif pajak lebih rendah dan tingkat kerahasiaan bank yang tinggi untuk melindungi informasi investor dari pengenaan pajak.

Pengelakan pajak dengan modus tersebut (biasa disebut juga dengan cross-border tax evasion oleh Casi et al (2018) biasa dilakukan di tingkat global. Hal ini berisiko signifikan dalam mengurangi penerimaan pajak dari individu atau perusahaan multinasional bagi negara yang bukan termasuk Tax Haven. Studi terkini menjelaskan bahwa pengelakan pajak memberikan kerugian penerimaan pajak sekitar US\$ 500 miliar setiap tahunnya di tingkat global dimana porsi kerugian yang paling besar terdapat pada negara-negara dengan Pendapatan Domestik Bruto (PDB) tingkat menengah kebawah, PDB tingkat rendah, dan negara-negara yang termasuk dalam Sub-Sahara Afrika, Amerika Latin, Karibia, dan Asia Selatan (Cobham dan Peter, 2018).

Dalam rangka memitigasi risiko pengelakan pajak di skala internasional, banyak negara maju melakukan perjanjian untuk melakukan pertukaran informasi tentang kepemilikan pendapatan resident di negara lain, yang dengan kata lain menghilangkan unsur kerahasiaan informasi nasabah bank untuk kepentingan perpajakan di negara tersebut. Negara-negara di Uni Eropa melakukannya pertama kali dengan EU Saving Directive pada tahun 2003, yang kemudian diadopsi oleh Amerika Serikat dengan membuat Foreign Account Tax Compliance (FACTA) di tahun 2010. Negara-negara yang termasuk dalam G20 juga turut berpatisipasi memperluas kerjasama pertukaran informasi ini. Organization of Economic Co-operation and Development (OECD) membantu negara-negara G20, negara berkembang, dan negara dunia ketiga untuk membuat kerangka konseptual dan standar pelaporan umum (biasa disebut Common Reporting Standard/CRS) untuk menjamin efektivitas dan efisiensi pertukaran informasi untuk kepentingan perpajakan di skala internasional.

Berdasarkan data OECD (2019), terdapat 49 negara yang melakukan pertukaran informasi pertama di tahun 2017, 53 negara yang melakukan pertukaran informasi pertama di tahun 2018, 5 negara yang akan melakukan pertukaran informasi pertamanya di tahun 2019 atau 2020, dan 42 negara-negara berkembang yang belum menetapkan waktu untuk melakukan pertukaran informasi pertamanya. Indonesia termasuk dalam 
kelompok negara yang telah melakukan otomasi pertukaran informasinya di tahun 2018.

Kata kunci : kepatuhan resident Indonesia, penghindaran pajak

\section{KERANGKA TEORITIS DAN PENGEMBANGAN HIPOTESIS}

\subsection{Studi Terdahulu}

E. Kirchler et al (2008) menjelaskan jenis kepatuhan wajib pajak terbagi menjadi dua berdasarkan kerangka kerja slippery slope, yaitu kepatuhan yang dipaksakan (enforced compliance) yang dipengaruhi oleh kekuatan otoritas pajak dan kepatuhan sukarela (voluntary compliance) yang dipengaruhi oleh kepercayaan wajib pajak terhadap otoritas pajak. Kekuatan otoritas pajak yang dimaksud E. Kirchler et al (2008) adalah persepsi wajib pajak terhadap kemampuan otoritas pajak untuk mendeteksi penghindaran pajak,misalnya pemantauan, pengawasan dan pemeriksaan rutin kewajiban perpajakan yang belum dipenuhi, dan kemampuan untuk menghukum pelaku yang melanggar ketentuan perpajakan, misalnya pengenaan sanksi denda yang setimpal terhadap pelaku penghindaran pajak. Kebijakan keterbukaan informasi perbankan dan pertukaran informasi untuk kepentingan perpajakan merupakan salah satu instrumen penting dalam meningkatkan kekuatan otoritas pajak untuk mempengaruhi persepsi wajib pajak yang nantinya akan berdampak pada kepatuhan yang dipaksakan.
Berbagai studi terdahulu yang berhubungan langsung dengan penelitian kebijakan pertukaran informasi menggunakan data cross-border deposit sebagai proksi cross-border transaction untuk mengetahui dampak penerapan kebijakan keterbukaan informasi perbankan dan pertukaran informasi internasional terhadap risiko penghindaran pajak dengan modus cross-border transaction melalui negara Tax Haven. Data tersebut oleh bank sentral tiap negara didefinisikan sebagai Locational Banking Statistics (LBS) dan dilaporkan tiap triwulan ke Bank International Settlement (BIS). BIS adalah organisasi internasional yang dimiliki oleh 60 bank sentral negara di dunia yang merepresentasikan sekitar 95\% PDB dunia dan memiliki misi untuk melayani bank sentral dalam pelaksanaan tugasnya untuk menjaga stabilitas finansial dan moneter, membina kerja sama internasional antar bank sentral, dan berperan sebagai bank untuk bank sentral.

Johannesen dan Zucman (2014) meneliti perubahan jumlah cross-border deposit warga negara Prancis yang ditempatkan di Swiss sebelum dan setelah diterapkannya perjanjian pertukaran informasi antara negara Prancis dan Swiss. Berdasarkan penelitiannya, terdapat penurunan jumlah cross-border deposit warga negara Prancis yang ditempatkan di Swiss sekitar $11 \%$ setelah diterapkannya perjanjian namun cross-border deposit tersebut tidak sepenuhnya dilakukan repatriasi, tetapi dialokasikan ke Tax Haven lain atau deklarasi di Tax Haven. Caruana-Galizia (2016) meneliti kecenderungan perilaku entitas yang berdomisili di Uni Eropa sebelum dan setelah 
diterapkannya Tax and Saving Directive Obliged menggunakan data perusahaan jasa keuangan offshore. yang menunjukkan kepemilikan keuntungan sebenarnya (Beneficial Owner). Data tersebut lebih signifikan saat dijadikan proksi cross-border transaction dibandingkan data cross-border deposit dari BIS yang bersifat agregat. Lebih lanjut, hasil penelitian ini juga menunjukkan bahwa dampak perubahan kepemilikan entitas Uni Eropa setelah penerapan Tax and Saving Directive Obliged memilki arah dan tingkat signifikansi yang sama seperti perubahan cross-border deposit Uni Eropa sehingga dapat diasumsikan bahwa penggunaan data cross-border deposit cukup relevan untuk dijadikan proksi cross-border transaction.

De Simone et al (2018) meneliti perubahan investasi asing yang ditanam di Amerika Serikat setelah penerapan FACTA dengan asumsi sebagai berikut: (1) investor cenderung ingin berinvestasi di domisilinya, (2) investor asing tidak terpengaruh oleh peraturan Pemerintah Amerika Serikat (3) Aset yang disembunyikan offshore sebagian besar ditempatkan di negara Tax Haven (4) data portofolio investasi asing dominan merepresentasikan investasi individu bukan korporasi. Hasil penelitian menunjukkan bahwa investasi asing di Amerika Serikat konsisten mengalami penurunan sejak diterapkanya FATCA dalam kisaran US\$56,6 - 78 miliar, seiring dengan penurunan tingkat investasi round-tripping dengan U.S. Mereka juga menemukan terdapat kenaikan investasi di bidang real estate dan karya seni karena dua sektor tersebut tidak termasuk dalam objek di FACTA.

Casi et al (2018) melakukan penelitian terhadap perubahan cross-border deposit milik resident OECD dan Uni Eropa yang ditempatkan di negara Tax Haven setelah diterapkannya Common Reporting Standard (CRS) untuk kepentingan pertukaran informasi. Hasil penelitiannya menunjukkan bahwa implementasi CRS mempengaruhi penurunan cross-border deposit resident OECD dan Uni Eropa yang ditempatkan di negara Tax Haven sebanyak $14 \%$ berdasarkan metode penelitian dengan estimasi difference-in-differences. Lebih lanjut, harta dan pendapatan terkait cross-border deposit tersebut tidak direpatriasi sepenuhnya melainkan direalokasikan ke negara yang cenderung tidak patuh terhadap ketentuan CRS. Casi et al (2018) membuktikan hal tersebut dengan menggunakan metode estimasi difference-in-differences pada kelompok negara yang tidak termasuk Tax Haven terhadap negara Amerika Serikat yang diklaim cenderung tidak patuh terhadap ketentuan CRS.

OECD (2019) melakukan penelitian pendahuluan untuk mengukur dampak transparansi informasi keuangan melalui kebijakan AEOI menggunakan data cross-border deposit dari Bank International Settlement (BIS) pada 38 yuridiksi dari tahun 2000 sampai dengan 2018 Pendekatan penelitian yang digunakan sama dengan penelitian Johannesen dan Zucman (2014) sehingga mendapatkan beberapa temuan sebagai berikut: (a) Deposit bank yang ditempatkan di institusi keuangan non-bank meningkat secara substansial dari tahun 2000 sampai dengan tahun 2008, (b) Deposit non-bank 
mengalami penurunan sekitar 34\% di kuarter pertama tahun 2018 apabila dibandingkan dengan posisi awal di tahun 2018, (c) Tren penurunan deposit non-bank tersebut yang berasal dari dampak keterbukaan informasi keuangan untuk transparansi perpajakan tidak dapat ditentukan secara presisi, tetapi analisis arus dana yang ditandai dengan diberlakukannya kebijakan pertukaran informasi menunjukkan bahwa kebijakan tersebut memang menjadi salah satu faktor penting yang menyebabkan penurunan tersebut. (d) Terdapat penurunan dalam kisaran 11 $12 \%$ atas deposit non-bank yang diakibatkan oleh implementasi kebijakan pertukaran informasi untuk transparansi perpajakan. Hal ini sama dengan temuan penelitian Johannesen dan Zucman (2014), dan (e) Diberlakukannya AEOI, yang didefinisikan sebagai tindak lanjut suatu yuridiksi untuk melakukan pertukaran informasi pertamanya dalam Common Reporting Standard (CRS) atau Foreign Account Tax Compliance Act (FATCA) Intergovernmental Agreement (IGA), mempengaruhi penurunan deposit non-bank sekitar 20 sampai $25 \%$.

\subsection{Rumusan Permasalahan}

Cobham dan Petr (2018) mengestimasi Indonesia mengalami kerugian pendapatan pajak akibat penghindaran pajak sekitar US $\$ 6,48$ miliar setiap tahunnya berdasarkan Government Data Revenue (GDR) atau US\$ 7,48 miliar setiap tahunnya berdasarkan data International Monetary Fund (IMF).
Dengan diberlakukannya Undang-Undang No. 9 Tahun 2017 tentang Keterbukaan Informasi Perbankan dan petunjuk teknis tentang pertukaran informasi yang tertuang di Peraturan Menteri Keuangan No. PMK-39/PMK.03/2017 pada kuartal II 2017 di Indonesia, seharusnya tingkat kepatuhan yang dipaksakan wajib pajak Indonesia dapat meningkat karena kekuatan otoritas pajak meningkat sehingga kerugian penerimaan pajak akibat pengelakan pajak dengan modus cross-border transaction dapat menurun.

Berdasarkan studi terdahulu, kita dapat memperkirakan kemungkinan perilaku kepatuhan wajib pajak yang melakukan pengelakan pajak dengan modus cross-border transaction menggunakan data cross-border deposit sebagai proksinya. Kemungkinan perilaku kepatuhan tersebut dijelaskan dalam dua pertanyaan sebagai berikut ;

1. Apakah resident Indonesia akan menarik cross-border deposit yang mereka tempatkan di Offshore Financial Centre setelah diberlakukannya kebijakan keterbukaan informasi perbankan dan pertukaran informasi internasional di Indonesia?

2. Apabila resident Indonesia terbukti menarik cross-border deposit mereka dari Offshore Financial Centre yang mengikuti ketentuan kebijakan pertukaran informasi, apakah cross-border deposit tersebut dilakukan repatriasi atau deklarasi di negara yang cenderung tidak patuh pada ketentuan pertukaran informasi?

Dalam penelitian ini, Penulis mengasumsikan bahwa resident Indonesia dinilai memenuhi kepatuhan yang dipaksakan apabila resident tersebut menarik cross-border deposit mereka dari Offshore Financial Centre 
mengalami penurunan sekitar 34\% di kuarter pertama tahun 2018 apabila dibandingkan dengan posisi awal di tahun 2018, (c) Tren penurunan deposit non-bank tersebut yang berasal dari dampak keterbukaan informasi keuangan untuk transparansi perpajakan tidak dapat ditentukan secara presisi, tetapi analisis arus dana yang ditandai dengan diberlakukannya kebijakan pertukaran informasi menunjukkan bahwa kebijakan tersebut memang menjadi salah satu faktor penting yang menyebabkan penurunan tersebut. (d) Terdapat penurunan dalam kisaran 11 $12 \%$ atas deposit non-bank yang diakibatkan oleh implementasi kebijakan pertukaran informasi untuk transparansi perpajakan. Hal ini sama dengan temuan penelitian Johannesen dan Zucman (2014), dan (e) Diberlakukannya AEOI, yang didefinisikan sebagai tindak lanjut suatu yuridiksi untuk melakukan pertukaran informasi pertamanya dalam Common Reporting Standard (CRS) atau Foreign Account Tax Compliance Act (FATCA) Intergovernmental Agreement (IGA), mempengaruhi penurunan deposit non-bank sekitar 20 sampai $25 \%$.

\subsection{Rumusan Permasalahan}

Cobham dan Petr (2018) mengestimasi Indonesia mengalami kerugian pendapatan pajak akibat penghindaran pajak sekitar US $\$ 6,48$ miliar setiap tahunnya berdasarkan Government Data Revenue (GDR) atau US\$ 7,48 miliar setiap tahunnya berdasarkan data International Monetary Fund (IMF).
Dengan diberlakukannya Undang-Undang No. 9 Tahun 2017 tentang Keterbukaan Informasi Perbankan dan petunjuk teknis tentang pertukaran informasi yang tertuang di Peraturan Menteri Keuangan No. PMK-39/PMK.03/2017 pada kuartal II 2017 di Indonesia, seharusnya tingkat kepatuhan yang dipaksakan wajib pajak Indonesia dapat meningkat karena kekuatan otoritas pajak meningkat sehingga kerugian penerimaan pajak akibat pengelakan pajak dengan modus cross-border transaction dapat menurun.

Berdasarkan studi terdahulu, kita dapat memperkirakan kemungkinan perilaku kepatuhan wajib pajak yang melakukan pengelakan pajak dengan modus cross-border transaction menggunakan data cross-border deposit sebagai proksinya. Kemungkinan perilaku kepatuhan tersebut dijelaskan dalam dua pertanyaan sebagai berikut ;

1. Apakah resident Indonesia akan menarik cross-border deposit yang mereka tempatkan di Offshore Financial Centre setelah diberlakukannya kebijakan keterbukaan informasi perbankan dan pertukaran informasi internasional di Indonesia?

2. Apabila resident Indonesia terbukti menarik cross-border deposit mereka dari Offshore Financial Centre yang mengikuti ketentuan kebijakan pertukaran informasi, apakah cross-border deposit tersebut dilakukan repatriasi atau deklarasi di negara yang cenderung tidak patuh pada ketentuan pertukaran informasi?

Dalam penelitian ini, Penulis mengasumsikan bahwa resident Indonesia dinilai memenuhi kepatuhan yang dipaksakan apabila resident tersebut menarik cross-border deposit mereka dari Offshore Financial Centre 
setelah diberlakukannya kebijakan keterbukaan informasi perbankan dan pertukaran informasi internasional. Asumsi tersebut berdasarkan pertimbangan bahwa apabila cross-border deposit mereka ditempatkan di negara yang bukan Offshore Financial Centre dan memenuhi ketentuan kebijakan pertukaran informasi maka otoritas pajak Indonesia memiliki kemampuan deteksi dini akan potensi pengelakan pajak karena mendapatkan informasi yang diperlukan dengan mekanisme pertukaran informasi nantinya yang secara jangka panjang mengurangi kecenderungan resident indonesia untuk melakukan pengelakan pajak dengan modus cross-border transaction.

\subsection{Tujuan Penelitian}

Tujuan penelitian dalam paper ini adalah untuk mengetahui:

1. Perilaku kepatuhan resident Indonesia terhadap cross-border deposit yang mereka tempatkan di Offshore Financial Centre setelah diimplementasikannya kebijakan keterbukaan informasi perbankan dan pertukaran informasi.

2. Perilaku kepatuhan resident Indonesia terhadap cross-border deposit yang mereka tarik dari Offshore Financial Centre yang menerapkan kebijakan keterbukaan informasi perbankan dan pertukaran informasi internasional apabila resident tersebut terbukti menarik cross-border deposit setelah diterapkan kebijakan pertukaran informasi.

\section{METODOLOGI PENELITIAN 3.1 Data Penelitian}

Data sekunder yang digunakan untuk memenuhi tujuan penelitian adalah data cross-border deposit, yaitu jumlah aset dan kewajiban resident yang ditempatkan di luar negeri sesuai dengan laporan setiap bank sentral di jurisdiksi luar negeri tersebut. Data ini terdiri dari deposito, pinjaman yang diberikan, surat hutang, obligasi dan instrumen keuangan lainnya milik resident yang ditempatkan di luar negeri yang dibagi dalam kelompok antar bank dan non-bank. Data tersebut direkapitulasi oleh BIS per kuartal. Data cross-border deposit yang digunakan dalam penelitian ini hanya cross-border deposit aset yang termasuk dalam kelompok non-bank, yang berarti ditempatkan di institusi keuangan selain bank, karena cross-border deposit antar bank tidak termasuk dalam ranah pengelakan pajak (Johannesen dan Zucman, 2014). Periode data yang digunakan penulis dalam penelitian ini adalah periode kuartal I Tahun 2008 sampai dengan kuartal I Tahun 2019 dengan pertimbangan sebagai berikut:

(a) OECD (2019) menggunakan periode tersebut untuk mengetahui signifikansi pengaruh dampak kebijakan AEOI untuk saat tren penurunan cross-border deposit yang ditempatkan di institusi non-bank terjadi di awal tahun 2008.

(b) Berdasarkan temuan pendahuluan OECD (2019), periode data penelitian di tahun 2008 sampai dengan kuartal I tahun 2019 dapat memberikan kesimpulan bahwa 2/3 penurunan cross-border deposit non-bank sejak tahun 2008 disebabkan oleh perjanjian pertukaran informasi dan sekitar 20\% hingga 25\% disebabkan oleh kebijakan AEOI. 
Setelah menentukan periode observasi, penulis menentukan yuridiksi yang termasuk Offshore Financial Centre. IMF (2000) mendefinisikan Offshore Financial Centre (OFC) sebagi suatu pusat aktivitas keuangan yang dilakukan di luar yuridiksi dimana sebagian besar lawan transaksinya adalah non-resident. Yuridiksi yang termasuk dalam definisi OFC tersebut dan melakukan pelaporan ke BIS adalah Bahama, Bahrain, Bermuda, Cayman Islands, Curacao, Cyprus, Guernsey, Hong Kong, Isle of Man, Jersey, Luxembourg, Macao, Malaysia, Panama, Singapura, dan Swiss. Penulis hanya menggunakan data cross-border deposit resident Indonesia yang ditempatkan di Guernsey, Hong Kong, Isle of Man, Jersey, Luxembourg, Macao, dan Swiss sebagai OFC karena hanya yuridiksi tersebut yang datanya tersedia di laman resmi BIS. Data cross-border deposit resident Indonesia yang ditempatkan di yuridiksi selain OFC yang tersedia di laman BIS antara lain sebagai berikut: Australia, Austria, Belgia, Brazil, Kanada, Chili, Taiwan, Denmark, Finlandia, Perancis, Jerman, Yunani, Irlandia, Italia, Jepang, Korea, Meksiko, Belanda, Filipina, Afrika Selatan, Spanyol, Swedia, Inggris Raya, dan Amerika Serikat. Penulis menyajikan data rata-rata cross-border deposit non-bank resident Indonesia tersebut dalam lampiran I.

Kelemahan data cross-border deposit yang disediakan BIS adalah sebagai berikut: (1) data ini tidak dapat menunjukkan secara spesifik pemilik keuntungan yang sebenarnya (benificial owner/BO), (2) data ini tidak dapat menunjukkan secara jelas kepemilikan nya berupa orang pribadi atau korporasi tetapi kekurangan ini tidak relevan untuk memahami dampak implementasi pertukaran informasi secara agregat, (3) portofolio ekuitas yang dapat dimanfaatkan oleh pelaku penghindaran pajak tidak termasuk dalam data cross-border deposit BIS (Casi et al, 2018) namun Johannesen dan Zucman (2014) berpendapat bahwa perubahan data deposito non-bank dapat dijadikan proksi yang memadai untuk mengetahui dampak perubahan perilaku pengelakkan pajak setelah diberlakukannya pertukaran informasi untuk kepentingan perpajakan.

\subsection{Metode Penelitian}

Penelitian menggunakan metode kuantitatif dengan estimasi difference-in-differences untuk mengetahui dampak cross-border deposit setelah diterapkannya kebijakan keterbukaan informasi perbankan dan pertukaran informasi. Estimasi difference-in-differences adalah teknik statistik ysang digunakan di ekonometrika dan penelitian kuantiatif dalam sosial sains yang mencoba meniru desain penelitian eksperimen menggunakan data observasi dengan meneliti perbedaan efek pada data yang ditempatkan pada kelompok yang diperlakukan khusus (treatment group) terhadap kelompok yang dikendalikan (control group) dalam eksperimental alami (Angrist et al, 2008,p. 227-243). Data cross-border deposit resident Indonesia yang dikelompokkan dalam treatment group akan diberikan perlakuan khusus dengan dibuatkan data dummy untuk mendapat gambaran perbedaan sebelum dan setelah kebijakan diterapkan. 
Data cross-border deposit resident Indonesia yang digunakan dalam penelitian ini adalah data periode kuartal I 2008 sampai dengan kuartal I 2019. Data setelah periode kuartal || 2017 termasuk dalam data yang harus diberikan perlakuan khusus karena pada periode tersebut aturan keterbukaan informasi perbankan dan pertukaran informasi diberlakukan.

Perlakuan kedua pada treatment group adalah membuat data dummy terhadap cross-border deposit resident Indonesia yang ditempatkan di OFC. (Casi et al, 2018) menempatkan negara Guemsey, Hong Kong, Isle of Man, Jersey, dan Macao sebagai sampel negara OFC dalam penelitiannya karena lima negara tersebut mencakup 40\% cross-border deposit dari 12 negara OFC yang datanya tersedia di BIS. Dalam penelitian ini, Penulis hanya menggunakan data cross-border deposit resident Indonesia yang ditempatkan di Guernsey, Hong Kong, Jersey, Luxembourg, Macao, dan Swiss sebagai OFC karena hanya yuridiksi tersebut yang datanya tersedia di laman resmi BIS. Cross-border deposit resident Indonesia yang ditempatkan di negara selain enam negara tersebut termasuk dalam control group yang berfungsi untuk mengakomodasi dampak perubahan yang terjadi bukan karena kebijakan keterbukaan dan pertukaran informasi, seperti resesi, pertumbuhan ekonomi, atau jarak antar negara (Casi et al, 2018).

Setelah mengelompokan data cross-border deposit resident Indonesia pada treatment group dan control group Penulis mengolah data tersebut dalam model regresi estimasi difference-in-differences sebagai berikut:

\section{Log (cross-border depositjt) $=\alpha+\beta$ 1cross-border depositjt * Offshore Financial Centre dummy $+\beta 2$ cross-bor- der depositjt * Post-AEOI Implemention dummy + €t}

Log (cross-border depositjt) adalah nilai log dari rata-rata cross-border deposit domisili Indonesia yang ditempatkan di luar negeri pada suatu kuartal tertentu. Offshore Financial Centre dummy adalah dummy yang nilainya 1 apabila negara yang menjadi tempat cross-border deposit resident Indonesia termasuk kelompok OFC dan Post-AEOI Implementation dummy adalah dummy yang nilainya 1 apabila periode cross-border deposit domisili Indonesia yang diolah termasuk dalam periode diatas Q2 2017. Detail data dari tiap variabel yang telah dijelaskan sebelumnya penulis sajikan di lampiran II.

Berdasarkan hasil penelitian terdahulu, Penulis mengestimasi bahwa terdapat dampak penurunan cross-border deposit resident Indonesia yang ada di Offshore Financial Centre yang berarti terdapat perpindahan cross-border deposit tersebut dari OFC ke non-OFC (Casi et al, 2018) mengungkapkan dalam penelitiannya bahwa cross-border deposit di negara Uni Eropa dan OECD yang keluar OFC setelah diterapkannya CRS tidak direpatriasi seluruhnya ke negara resident, tetapi sebagian pindah ke negara yang cenderung tidak patuh pada ketentuan CRS, yaitu Amerika Serikat (Swanson, 2016, April 5).

Selanjutnya, Swanson (2016, April 5) menyebutkan bahwa Tax Justice Network menilai Amerika Serikat termasuk 
dalam negara yang cenderung tidak patuh pada ketentuan CRS karena ketentuan FACTA Intergovernmental Agreements (IGA) yang digunakan Amerika Serikat untuk kepentingan pertukaran informasi tidak bersifat resiprokal seperti ketentuan CRS. Beberapa faktor yang mendukung penilaian mereka adalah sebagai berikut: (1) FACTA IGA secara kontekstual lebih mengarah pada hubungan bilateral, bukan multilateral seperti yang diarahkan ketentuan CRS, (2) proses bisnis bank domestik Amerika Serikat kurang kuat untuk memastikan informasi beneficial owner suatu entitas yang sebenarnya di Amerika Serikat, (3) bank Amerika Serikat hanya bersedia memberikan informasi keuangan berupa deposito individu apabila negara lain meminta informasi keuangan individunya, (4) FACTA IGA tidak mengharuskan pemerintah Amerika Serikat memberikan informasi identitas controlling person dari Non-Financial Entities (NFE) dan non-entitas negara yang meminta informasi, (5) FACTA IGA tidak mengharuskan pemerintah Amerika Serikat memberikan informasi saldo rekening, omzet dari penjualan, dan hak penebusan atas kepemilikan properti.

\section{Log (cross-border depositijt) $=\alpha+\beta$ 1cross-border depositjt * Amerika Serikat dummy $+\beta 2$ cross-border depositjt * Post-AEOI Implemention dummy $+€ t$}

*Penulis menyajikan data tiap variabel model tersebut di lampiran III.

\section{HASIL DAN PEMBAHASAN}

\subsection{Hasil Penelitian}

Berdasarkan data cross-border deposit resident Indonesia dan model regresi yang telah ditentukan, estimasi difference-in-differences di tabel 4.1. menunjukkan bahwa terdapat penurunan di kisaran 49,6\%. Hal ini berarti bahwa resident Indonesia menarik cross-border deposit mereka yang ditempatkan di OFC sebanyak 49,6\% setelah diterapkannya kebijakan keterbukaan informasi perbankan dan pertukaran informasi internasional.

Hasil penelitian ini menjawab pertanyaan penelitian bahwa resident Indonesia memenuhi kepatuhan yang dipaksakan dengan menarik cross-border deposit mereka dari OFC setelah diterapkannya kebijakan keterbukaan informasi perbankan dan pertukaran informasi internasional. Tingkat penurunan cross-border deposit tersebut lebih besar apabila dibandingkan dengan tingkat penurunan cross-border deposit negara anggota OECD dan Uni Eropa yang hanya sebesar $14 \%$ sesuai dengan penelitian Casi et al (2018).

Tujuan penelitian berikutnya adalah membuktikan apakah cross-border deposit resident Indonesia yang sudah ditarik dari negara OFC dilakukan repatriasi atau dideklarasi ke negara yang cenderung tidak patuh pada ketentuan pertukaran informasi dan keterbukaan informasi perbankan. 
Tabel 4.1. Perubahan Cross-Border Deposit resident Indonesia yang ditempatkan di OFC setelah Implementasi Keterbukaan dan Pertukaran Informasi

\begin{tabular}{|l|c|c|c|c|c|}
\hline \multicolumn{5}{|c|}{ Variabel Dependen : Log Cross-border deposit resident Indonesia } \\
\hline $\begin{array}{c}\text { Variabel } \\
\text { Independen }\end{array}$ & Koefisien & $\begin{array}{c}\mathrm{R} \\
\text { Squared }\end{array}$ & Observasi & Prob> F & Std. Error. \\
\hline OFC Dummy & $-0.1580791^{\star}$ & & & & 0.7035688 \\
\hline $\begin{array}{l}\text { Post AEOI } \\
\text { Implementation } \\
\text { Dummy }\end{array}$ & $0.4049037^{\star}$ & \multirow{2}{*}{0,091} & 124 & 0,7765 & 0.3996003 \\
\hline $\begin{array}{l}\text { Difference In } \\
\text { Difference }\end{array}$ & $-0.4964799^{\star}$ & & & 0.9949966 \\
\hline
\end{tabular}

\section{Sumber: Penulis, data diolah sendiri}

Data yang digunakan untuk menguji estimasi difference-in-differences adalah cross-border deposit resident Indonesia yang ditempatkan di OFC selain Amerika Serikat terhadap Amerika serikat. Berdasarkan data yang diperoleh dan model regresi yang sudah ditentukan, diketahui bahwa estimasi difference-in-differences di Amerika Serikat sebesar 23,86\%. Hal ini menunjukkan bahwa cross-border deposit resident Indonesia yang sudah keluar dari OFC setelah diberlakukannya kebijakan keterbukaan informasi perbankan dan pertukaran informasi internasional beralih ke negara yang cenderung tidak mematuhi ketentuan kebijakan tersebut sebesar 23,86\%. Tingkat pemindahan cross-border deposit tersebut lebih besar apabila dibandingkan dengan tingkat pemindahan cross border deposit dari negara anggota OECD dan Uni Eropa ke Amerika Serikat sebesar 8,5\% sesuai penelitian Casi et al (2018).

Tabel 4.2. Perubahan Cross-Border Deposit Resident Indonesia yang Ditempatkan di Amerika Serikat terhadap Negara non-OFC selain Amerika Serikat setelah Implementasi Kebijakan Keterbukaan dan Pertukaran Informasi

\begin{tabular}{|l|c|c|c|c|c|}
\hline \multicolumn{5}{|c|}{ Variabel Independen : Log Cross-border deposit resident Indonesia } \\
\hline $\begin{array}{c}\text { Variabel } \\
\text { Independen }\end{array}$ & Koefisien & $\begin{array}{c}\mathrm{R} \\
\text { Squared }\end{array}$ & Observasi & Prob>F & Std. Error. \\
\hline $\begin{array}{l}\text { Negara Amerika } \\
\text { Serikat Dummy }\end{array}$ & $0.0536549^{*}$ & & & & 0.6375474 \\
\cline { 1 - 2 } $\begin{array}{l}\text { Post AEOI } \\
\text { Implementation } \\
\text { Dummy }\end{array}$ & $0.9805167^{*}$ & \multirow{2}{*}{0,0226} & 62 & 0,7201 & 3.701783 \\
\hline $\begin{array}{l}\text { Difference In } \\
\text { Difference }\end{array}$ & $0.2382081^{*}$ & & & 4.086659 \\
\hline
\end{tabular}

Sumber : Penulis, data diolah sendiri 


\section{KESIMPULAN}

Berdasarkan hasil penelitian, kesimpulan yang didapat untuk menjawab rumusan permasalahan adalah kebijakan keterbukaan informasi perbankan dan pertukaran informasi internasional mempengaruhi perilaku kepatuhan yang dipaksakan resident Indonesia untuk menarik cross-border deposit mereka dari OFC sebesar 49,64\%.

Namun cross-border deposit resident Indonesia yang telah ditarik dari OFC tidak sepenuhnya dilakukan repatriasi. Ada sebagian cross-border deposit tersebut yang dipindahkan resident Indonesia ke negara yang cenderung tidak patuh terhadap ketentuan kebijakan keterbukaan informasi perbankan dan pertukaran informasi internasional sebesar 23,82\%.

\section{IMPLIKASI DAN KETERBATASAN}

Berdasarkan kesimpulan yang diperoleh, penulis memberikan saran sebagai berikut: 1. Kebijakan keterbukaan informasi perbankan dan pertukaran informasi internasional terbukti memberikan dampak yang positif untuk meningkatkan kepatuhan yang dipaksakan resident Indonesia untuk menarik cross-border deposit mereka dari OFC walaupun otomisasi pertukaran informasi baru dilakukan pertama kali pada September 2018. Direktorat Jenderal Pajak selaku pelaksana kebijakan keterbukaan dan pertukaran informasi untuk kepentingan perpajakan di Indonesia perlu menyediakan infrastruktur dan sumber daya yang memadai untuk memperkuat dampak tersebut, terutama dari sisi teknologi informasi, untuk menjamin kelancaran pertukaran informasi keuangan.
2. Dalam rangka meningkatkan efektivitas pertukaran informasi internasional untuk kepentingan perpajakan, Direktorat Jenderal Pajak dapat memperkuat regulasi dengan menambah detail jenis informasi yang diminta, terutama untuk mengetahui beneficial owner dan controlling person suatu entitas yang melakukan cross-border transaction dengan negara mitra.

\section{DAFTAR PUSTAKA}

[1] Angrist, J. D.; Pischke, J. S. (2008). Mostly Harmless Econometrics: An Empiricist's Companion. Princeton University Press. pp. 227-243.

[2] Bank for International Settlements. (2017). Banks' Cross-border Positions on Residents of Indonesia [data file]. Diakses dari http://stats.bis.org/statx/srs/table/A6.2?c=ID\&p=20171

[3] Casi Elisa, Chrristoph Spengel, dan Barbara Stage. (2018). Cross-border tax evasion after the Common Reporting Standard: Game Over?. Discussion Paper No. 18-036.

[4] Caruana-Galizia, P., \& Caruana-Galizia, M. (2016). Offshore financial activity and tax policy: evidence from a leaked data set. Journal of Public Policy, 36.3: 457-488.

[5] Cobham Alex \& Petr Jansky. (2018). Global Distribution Of Revenue Loss From Corporate Tax Avoidance: Re-Estimation and Country Results. Journal of International Development. 30, 206-232.

[6] De Simone, L., Lester, R., \& Markle, K. (2018). Transparency and Tax Evasion: Evidence from the Foreign Account Tax Compliance Act (FATCA). Working Paper, Stanford.

[7] International Monetary Fund (2000). Offshore Financial Centers - IMF Background Paper. https://www.imf.org/external/np/mae/oshore/2000/eng/back.htm (diakses pada tanggal 26 Agustus 2019).

[8] Johannesen, N., \& Zucman, G. (2014). The End of Bank Secrecy? An Evaluation of the G20. Tax Haven Crackdown. American Economic Journal: Economic Policy, 6: 65-91.

[9] Organisation for Economic Co-operation and Development (2019). Using Bank Deposit 
Data to Assess the Impact of Exchange of Information. https://www.oecd.org/tax/exchange-of-tax-information/using-bank-deposit-data-to-assess-the-impact-ofexchange-of-information.pdf (diakses pada tanggal 26 Agustus 2019)

[10] Organisation for Economic Co-operation and Development (2019). Automatic Exchange Portal. http://www.oecd.org/tax/ a u to matic-exchange/com mit ment-and-monitoring-process/ (diakses pada tanggal 26 Agustus 2019)
[11] Swanson, Ana. (2016, April 5). How the U.S. became one of the world's biggest tax havens. The Washington Post. https://www.washington pos t. com/news/wonk/wp/2016/04/05/how-the-u-s-became-one-of-t he-worlds-biggest-tax-havens/ (diakses pada tanggal 26 Agustus 2019)

[12] Tax Justice Network. (2018). Financial Secrecy Index 2018: Narrative Report on USA. http://www.financialsecrecyindex.com/PDF/USA.pdf (diakses pada tanggal 26 Agustus 2019)

\section{LAMPIRAN}

\section{Lampiran I}

Rata-rata Cross Border Deposit Non-Bank Resident Indonesia per tahun (dalam jutaan US\$)

\begin{tabular}{|c|c|c|c|c|c|c|c|c|c|c|c|c|}
\hline \multirow[b]{2}{*}{$\begin{array}{l}\text { Tempat } \\
\text { Deposit }\end{array}$} & \multicolumn{12}{|c|}{ Rata-rata Cross Border Deposit Non-Bank Resident Indonesia per tahun (dalam jutaan US\$) } \\
\hline & 2008 & 2009 & 2010 & 2011 & 2012 & 2013 & 2014 & 2015 & 2016 & 2017 & 2018 & 2019(Q1) \\
\hline Australia & 253,75 & 242,75 & 344 & 396,75 & 608,25 & 673 & 828,75 & 862,5 & 922,5 & 823,75 & 789 & 731 \\
\hline Austria & 1671,75 & 1511,25 & 1335 & 1278,5 & 1137,75 & 1055,5 & 918,75 & 883,75 & 863,5 & 661,25 & 525,25 & 454 \\
\hline Belgium & 442 & 602,5 & 823,25 & 846,5 & 962,75 & 975,25 & 958,75 & 919,5 & 371 & 115,75 & 96 & 88 \\
\hline Brazil & 0 & 0 & 0 & 0 & 0 & 0 & 0 & 0 & 0,25 & 0 & 0 & 0 \\
\hline Canada & 0 & 0 & 0 & 0 & 0 & 0 & 0 & 2,25 & 25,5 & 10 & 8,75 & 8 \\
\hline Chille & 0 & 0 & 0 & 0 & 0 & 0 & 0 & 0 & 0 & 0 & 0 & 0 \\
\hline Chinese Taipei & 187,5 & 164,75 & 157 & 225,75 & 342,75 & 664,25 & 793,5 & 985,25 & 1055,75 & 1127,25 & 1339,75 & 1511 \\
\hline Denmark & 10,25 & 8 & 7 & 8,25 & 14,75 & 19,25 & 18 & 15,75 & 17,5 & 11,75 & 12,5 & 12 \\
\hline Finland & 70,75 & 66,25 & 49,75 & 0 & 0 & 0 & 0,25 & 0 & 0,5 & 1 & 1,25 & 1 \\
\hline France & 485,75 & 1015,25 & 1415,75 & 1635,25 & 1587 & 1341,25 & 1565,5 & 1733,75 & 1885,75 & 2085,5 & 2265,5 & 2602 \\
\hline Germany & 0 & 0 & 0 & 0 & 0 & 0 & 0 & 0 & 0 & 0 & 0 & 0 \\
\hline Greece & 0 & 0 & 0 & 0 & 0 & 0 & 0 & 0 & 0 & 0 & 0 & 0 \\
\hline Guemsey & 0 & 0 & 0 & 0 & 0 & 0 & 0,25 & 0,75 & 1,25 & 2 & 2 & 2 \\
\hline $\begin{array}{l}\text { Hong Kong } \\
\text { SAR }\end{array}$ & 0 & 0 & 0 & 0 & 0 & 0 & 557,75 & 2415,5 & 2686,75 & 2569,25 & 2624,75 & 2643 \\
\hline Ireland & 29,25 & 12 & 6,5 & 8,25 & 0,5 & 0,75 & 0 & 0 & 0 & 0 & 1 & 1 \\
\hline Isle of Man & 0 & 0 & 1,25 & 3,5 & 4 & 4 & 4,5 & 6 & 3,5 & 2 & 2 & 2 \\
\hline Italy & 0 & 0 & 0 & 0 & 0 & 0 & 10,5 & 38,75 & 66 & 20,5 & 21,5 & 36 \\
\hline Japan & 0 & 0 & 0 & 0 & 0 & 0 & 0 & 0 & 2018,75 & 0 & 0 & 0 \\
\hline Jersey & 5,5 & 6,75 & 5,5 & 6,25 & 6,5 & 124,25 & 242,75 & 244,75 & 125,5 & 13,5 & 37,75 & 37 \\
\hline Korea & 1018,75 & 846,5 & 748,5 & 926,75 & 1247,75 & 2899,5 & 3713,75 & 4495,5 & 4533 & 4529,75 & 4503,75 & 4312 \\
\hline Luxembourg & 5,25 & 0,75 & 2 & 73,5 & 86,25 & 94 & 5,75 & 8,5 & 9 & 52,25 & 81,5 & 13 \\
\hline Macao SAR & 0 & 0 & 0 & 0 & 0 & 0 & 0,5 & 0 & 0,75 & 0 & 1 & 17 \\
\hline Mexico & 0 & 0 & 0 & 0 & 0 & 0 & 0 & 0 & 0 & 0 & 0 & 0 \\
\hline Netherlands & 0 & 0 & 0 & 0 & 0 & 0 & 186,75 & 640 & 503,25 & 279,25 & 213 & 148 \\
\hline Phillipines & 0 & 0 & 0 & 0 & 0 & 0 & 0 & 0 & 375,75 & 586,75 & 509 & 518 \\
\hline South Africa & 0 & 0 & 0 & 25 & 24,75 & 13,25 & 0 & 0 & 0 & 0 & 0 & 0 \\
\hline Spain & 0 & 0 & 0 & 0 & 0 & 0 & 58,5 & 39 & 30,75 & 52,5 & 91 & 103 \\
\hline Sweden & 85 & 431 & 488,5 & 602 & 544,75 & 337 & 0 & 0 & 0 & 0 & 0 & 0 \\
\hline Switzerland & 376,25 & 416,75 & 546 & 572,25 & 560,25 & 636,5 & 578 & 520,25 & 488,75 & 399,75 & 367 & 359 \\
\hline U.K. & 911,75 & 789 & 668,75 & 716,25 & 698 & 1084,5 & 1481,25 & 1301,75 & 1257,5 & 863,25 & 1041,75 & 1379 \\
\hline U.S. & 249,75 & 183,25 & 73,5 & 186 & 312,5 & 358 & 315,5 & 288,5 & 325,5 & 401,75 & 405,5 & 357 \\
\hline
\end{tabular}

Sumber : http://stats.bis.org/statx/srs/table/A6.2?c=ID\&p=20171 


\section{LAMPIRAN}

Lampiran II

Detail Data tiap Variabel untuk Model Difference-in-Differences I

\begin{tabular}{|c|c|c|c|c|}
\hline $\begin{array}{l}\text { Tempat } \\
\text { Deposit }\end{array}$ & $\begin{array}{c}\text { Rata-rata CBD Resident } \\
\text { Indonesia }\end{array}$ & $\begin{array}{c}\text { Log CBD } \\
\text { Resident } \\
\text { Indonesia }\end{array}$ & $\begin{array}{c}\text { Dummy Pre/Post } \\
\text { AEOI Implementation }\end{array}$ & $\begin{array}{c}\text { Dummy } \\
\text { OFC/Non-OFC }\end{array}$ \\
\hline Australia & 582,5 & 2,76529593 & 0 & 0 \\
\hline Austria & 1159,473684 & 3,064260896 & 0 & 0 \\
\hline Belgium & 732,9473684 & 2,86507279 & 0 & 0 \\
\hline Brazil & 0,026315789 & $-1,579783597$ & 0 & 0 \\
\hline Canada & 3,447368421 & 0,537487699 & 0 & 0 \\
\hline Chille & 0 & 0 & 0 & 0 \\
\hline Chinese Taipei & 538 & 2,730782276 & 0 & 0 \\
\hline Denmark & 13,10526316 & 1,117445746 & 0 & 0 \\
\hline Finland & 19,78947368 & 1,296434244 & 0 & 0 \\
\hline France & 1437,526316 & 3,157615804 & 0 & 0 \\
\hline Germany & 0 & 0 & 0 & 0 \\
\hline Greece & 0 & 0 & 0 & 0 \\
\hline Guemsey & 0,342105263 & $-0,465840244$ & 0 & 1 \\
\hline $\begin{array}{l}\text { Hong Kong } \\
\text { SAR }\end{array}$ & 730,3421053 & 2,863526339 & 0 & 1 \\
\hline Ireland & 6,026315789 & 0,780051886 & 0 & 0 \\
\hline Isle of Man & 2,921052632 & 0,465539382 & 0 & 1 \\
\hline Italy & 13,44736842 & 1,128637304 & 0 & 0 \\
\hline Japan & 212,5 & 2,327358934 & 0 & 0 \\
\hline Jersey & 81,07894737 & 1,908908102 & 0 & 1 \\
\hline Korea & 2386,210526 & 3,377708757 & 0 & 0 \\
\hline Luxembourg & 30,63157895 & 1,486169384 & 0 & 1 \\
\hline Macao SAR & 0,131578947 & $-0,880813592$ & 0 & 1 \\
\hline Mexico & 0 & 0 & 0 & 0 \\
\hline Netherlands & 156,8157895 & 2,195389789 & 0 & 0 \\
\hline Phillipines & 70,18421053 & 1,846239419 & 0 & 0 \\
\hline South Africa & 6,631578947 & 0,821616944 & 0 & 0 \\
\hline Spain & 15,73684211 & 1,196917587 & 0 & 0 \\
\hline Sweden & 261,9210526 & 2,418170407 & 0 & 0 \\
\hline Switzerland & 516,2631579 & 2,712871134 & 0 & 1 \\
\hline U.K. & 980,0263158 & 2,991237738 & 0 & 0 \\
\hline U.S. & 261,8947368 & 2,418126771 & 0 & 0 \\
\hline Australia & 796,5714286 & 2,901224725 & 1 & 0 \\
\hline Austria & 537,5714286 & 2,730436178 & 1 & 0 \\
\hline Belgium & 98,42857143 & 1,993121182 & 1 & 0 \\
\hline Brazil & 0 & 0 & 1 & 0 \\
\hline Canada & 9 & 0,954242509 & 1 & 0 \\
\hline Chille & 0 & 0 & 1 & 0 \\
\hline
\end{tabular}




\section{LAMPIRAN}

(sambungan) Lampiran II

Detail Data tiap Variabel untuk Model Difference-in-Differences I

\begin{tabular}{|c|c|c|c|c|}
\hline $\begin{array}{l}\text { Tempat } \\
\text { Deposit }\end{array}$ & $\begin{array}{c}\text { Rata-rata CBD Resident } \\
\text { Indonesia }\end{array}$ & $\begin{array}{l}\text { Log CBD Resident } \\
\text { Indonesia }\end{array}$ & $\begin{array}{l}\text { Dummy Pre/Post AEOI } \\
\text { Implementation }\end{array}$ & $\begin{array}{c}\text { Dummy OFC/Non- } \\
\text { OFC }\end{array}$ \\
\hline Chinese Taipei & 1320,142857 & 3,12062093 & 1 & 0 \\
\hline Denmark & 12,28571429 & 1,089400411 & 1 & 0 \\
\hline Finland & 1,142857143 & 0,057991947 & 1 & 0 \\
\hline France & 2291,571429 & 3,360133399 & 1 & 0 \\
\hline Germany & 0 & 0 & 1 & 0 \\
\hline Greece & 0 & 0 & 1 & 0 \\
\hline Guemsey & 2 & 0,301029996 & 1 & 1 \\
\hline Hong Kong SAR & 2615,142857 & 3,417495418 & 1 & 1 \\
\hline Ireland & 0,714285714 & $-0,146128036$ & 1 & 0 \\
\hline Isle of Man & 2 & 0,301029996 & 1 & 1 \\
\hline Italy & 22 & 1,342422681 & 1 & 0 \\
\hline Japan & 0 & 0 & 1 & 0 \\
\hline Jersey & 33,14285714 & 1,520389945 & 1 & 1 \\
\hline Korea & 4498,571429 & 3,653074621 & 1 & 0 \\
\hline Luxembourg & 74,85714286 & 1,874233247 & 1 & 1 \\
\hline Macao SAR & 3 & 0,477121255 & 1 & 1 \\
\hline Mexico & 0 & 0 & 1 & 0 \\
\hline Netherlands & 211,1428571 & 2,324576394 & 1 & 0 \\
\hline Phillipines & 533,8571429 & 2,727425058 & 1 & 0 \\
\hline South Africa & 0 & 0 & 1 & 0 \\
\hline Spain & 84,57142857 & 1,927223667 & 1 & 0 \\
\hline Sweden & 0 & 0 & 1 & 0 \\
\hline Switzerland & 369,7142857 & 2,567866232 & 1 & 1 \\
\hline U.K. & 1056,142857 & 3,023722666 & 1 & 0 \\
\hline U.S. & 400,5714286 & 2,602679969 & 1 & 0 \\
\hline
\end{tabular}




\section{LAMPIRAN}

Lampiran III

Detail Data tiap Variabel untuk Model Difference-in-Differences II

\begin{tabular}{|c|c|c|c|c|}
\hline $\begin{array}{l}\text { Tempat } \\
\text { Deposit }\end{array}$ & $\begin{array}{c}\text { Rata-rata CBD Resident } \\
\text { Indonesia }\end{array}$ & $\begin{array}{c}\text { Log CBD } \\
\text { Resident } \\
\text { Indonesia }\end{array}$ & $\begin{array}{c}\text { Dummy Pre/Post } \\
\text { AEOI Implementation }\end{array}$ & $\begin{array}{c}\text { Dummy CBD } \\
\text { Resident } \\
\text { Indonesia di } \\
\text { Amerika Serikat }\end{array}$ \\
\hline Australia & 582,5 & 2,76529593 & 0 & 0 \\
\hline Austria & 1159,473684 & 3,064260896 & 0 & 0 \\
\hline Belgium & 732,9473684 & 2,86507279 & 0 & 0 \\
\hline Brazil & 0,026315789 & $-1,579783597$ & 0 & 0 \\
\hline Canada & 3,447368421 & 0,537487699 & 0 & 0 \\
\hline Chille & 0 & 0 & 0 & 0 \\
\hline Chinese Taipei & 538 & 2,730782276 & 0 & 0 \\
\hline Denmark & 13,10526316 & 1,117445746 & 0 & 0 \\
\hline Finland & 19,78947368 & 1,296434244 & 0 & 0 \\
\hline France & 1437,526316 & 3,157615804 & 0 & 0 \\
\hline Germany & 0 & 0 & 0 & 0 \\
\hline Greece & 0 & 0 & 0 & 0 \\
\hline Guemsey & 0,342105263 & $-0,465840244$ & 0 & 1 \\
\hline $\begin{array}{l}\text { Hong Kong } \\
\text { SAR }\end{array}$ & 730,3421053 & 2,863526339 & 0 & 1 \\
\hline Ireland & 6,026315789 & 0,780051886 & 0 & 0 \\
\hline Isle of Man & 2,921052632 & 0,465539382 & 0 & 1 \\
\hline Italy & 13,44736842 & 1,128637304 & 0 & 0 \\
\hline Japan & 212,5 & 2,327358934 & 0 & 0 \\
\hline Jersey & 81,07894737 & 1,908908102 & 0 & 0 \\
\hline Korea & 2386,210526 & 3,377708757 & 0 & 0 \\
\hline Luxembourg & 30,63157895 & 1,486169384 & 0 & 0 \\
\hline Macao SAR & 0,131578947 & $-0,880813592$ & 0 & 0 \\
\hline Mexico & 0 & 0 & 0 & 0 \\
\hline Netherlands & 156,8157895 & 2,195389789 & 0 & 0 \\
\hline Phillipines & 70,18421053 & 1,846239419 & 0 & 0 \\
\hline South Africa & 6,631578947 & 0,821616944 & 0 & 0 \\
\hline Spain & 15,73684211 & 1,196917587 & 0 & 0 \\
\hline Sweden & 261,9210526 & 2,418170407 & 0 & 0 \\
\hline Switzerland & 516,2631579 & 2,712871134 & 0 & 0 \\
\hline U.K. & 980,0263158 & 2,991237738 & 0 & 0 \\
\hline U.S. & 261,8947368 & 2,418126771 & 0 & 1 \\
\hline
\end{tabular}




\section{LAMPIRAN}

(lanjutan) Lampiran III

Detail Data tiap Variabel untuk Model Difference-in-Differences II

\begin{tabular}{|c|c|c|c|c|}
\hline $\begin{array}{l}\text { Tempat } \\
\text { Deposit }\end{array}$ & $\begin{array}{c}\text { Rata-rata CBD Resident } \\
\text { Indonesia }\end{array}$ & $\begin{array}{l}\text { Log CBD Resident } \\
\text { Indonesia }\end{array}$ & $\begin{array}{l}\text { Dummy Pre/Post AEOI } \\
\text { Implementation }\end{array}$ & $\begin{array}{c}\text { Dummy CBD } \\
\text { Resident } \\
\text { Indonesia di } \\
\text { Amerika Serikat }\end{array}$ \\
\hline Australia & 796,5714286 & 2,901224725 & 1 & 0 \\
\hline Austria & 537,5714286 & 2,730436178 & 1 & 0 \\
\hline Belgium & 98,42857143 & 1,993121182 & 1 & 0 \\
\hline Brazil & 0 & 0 & 1 & 0 \\
\hline Canada & 9 & 0,954242509 & 1 & 0 \\
\hline Chille & 0 & 0 & 1 & 0 \\
\hline Chinese Taipei & 1320,142857 & 3,12062093 & 1 & 0 \\
\hline Denmark & 12,28571429 & 1,089400411 & 1 & 0 \\
\hline Finland & 1,142857143 & 0,057991947 & 1 & 0 \\
\hline France & 2291,571429 & 3,360133399 & 1 & 0 \\
\hline Germany & 0 & 0 & 1 & 0 \\
\hline Greece & 0 & 0 & 1 & 0 \\
\hline Guemsey & 2 & 0,301029996 & 1 & 0 \\
\hline Hong Kong SAR & 2615,142857 & 3,417495418 & 1 & 0 \\
\hline Ireland & 0,714285714 & $-0,146128036$ & 1 & 0 \\
\hline Isle of Man & 2 & 0,301029996 & 1 & 0 \\
\hline Italy & 22 & 1,342422681 & 1 & 0 \\
\hline Japan & 0 & 0 & 1 & 0 \\
\hline Jersey & 33,14285714 & 1,520389945 & 1 & 0 \\
\hline Korea & 4498,571429 & 3,653074621 & 1 & 0 \\
\hline Luxembourg & 74,85714286 & 1,874233247 & 1 & 0 \\
\hline Macao SAR & 3 & 0,477121255 & 1 & 0 \\
\hline Mexico & 0 & 0 & 1 & 0 \\
\hline Netherlands & 211,1428571 & 2,324576394 & 1 & 0 \\
\hline Phillipines & 533,8571429 & 2,727425058 & 1 & 0 \\
\hline South Africa & 0 & 0 & 1 & 0 \\
\hline Spain & 84,57142857 & 1,927223667 & 1 & 0 \\
\hline Sweden & 0 & 0 & 1 & 0 \\
\hline Switzerland & 369,7142857 & 2,567866232 & 1 & 0 \\
\hline U.K. & 1056,142857 & 3,023722666 & 1 & 0 \\
\hline U.S. & 400,5714286 & 2,602679969 & 1 & 1 \\
\hline
\end{tabular}

